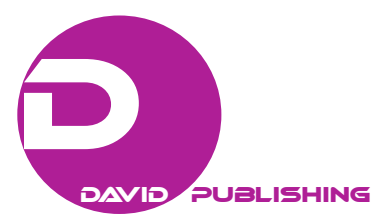

\title{
Pyramid Culture and Power Distance: Intangible Barriers Restricting Democratization*
}

\author{
Chanida Jittaruttha \\ Chulalongkorn University, Bangkok, Thailand
}

\begin{abstract}
Cultural theorists in postmodern approach have suggested that culture is a critical factor of the facts, derived from social values, which were given as socially constructed realities. This research paper was aimed to explore Thai people's attitude and perceive culture as a social culture that facilitates or hinders a democratic political regime. The assumption was that Thai social culture is a culture of pyramid schemes or authoritarian one, which is a major barrier to democratization, by determining "power distance" factor at three levels: (a) general level of social norms and relationships; (b) organizational or workplace relationships level; and (c) political or state relationships level. The hypothesis is that the higher the three levels of power distance in Thai people's perception are, the lesser the democracy strength is. The methodology employed in this research is the mixed method conducted by analyzing academic works as well as a field survey. The article postulates that Thai culture is shaped in pyramid scheme or authoritarian culture, since the power distance perceived culture at three levels was very high and directly influenced to Thai political culture in "pyramid" style, which has led Thai society into weak democracy in four dimensions. The pancake scheme or participative culture should have been promoted instead, among four dimensions with successful indicators: (a) cultural dimension: small power distance; (b) historical sociology dimension: reduction of obedience and more freedom of decision; (c) organizational society dimension: participation and decentralization; and (d) political economy dimension: accountability and transparency. Democratization of Thai society will be strengthened by reducing inequality rooted upon nepotism, patronage or spoils system and by eliminating corruption.
\end{abstract}

Keywords: power distance, pyramid culture, inequality, democratization

\section{Introduction}

Cultural theorists in postmodern approach have suggested that culture is a critical factor of the facts, derived from social values, which were given as socially constructed realities (Morgan, 1986). This research resulted from the awareness of social culture's importance, since "social culture" plays a primary role in social studies by comprehension given of value and behavioral disparity among people in each society. Culture is

\footnotetext{
* Acknowledgement: This exploratory research was a Thailand Democracy Watch Commissioned Research, Faculty of Political Science, Chulalongkorn University, Thailand. The author would like to thank Professor Dr. Supachai Yavaprabhas for his contribution to this study.

Chanida Jittaruttha, Ph.D., associate professor, lecturer at Public Administration Department, Former Director of Doctor of Philosophy in Political Science Program, Deputy Director of Master of Arts in Governance Program, Faculty of Political Science, Chulalongkorn University, Bangkok, Thailand.

Correspondence concerning this article should be addressed to Chanida Jittaruttha, Faculty of Political Science, Chulalongkorn University, Henri-Dunant Rd., Phayathai, Bangkok 10330, Thailand. E-mail: Chanida.Ji@chula.ac.th; chanida.jittaruttha@gmail.com.
} 
considered to be the group-specific behavior that is acquired, at least in part, from social influences and determines the patterns of behavior and social institutions of each society. In addition, culture is a social control mechanism by the standards of conduct in society and continually improves life expectancy, which became a social personality or national identity, for many generations. Cultural patterns are characterized by including beliefs, attitudes, values, norms, and roles evolved with cultural time and space, such as exact geographical boundaries or different periods of cultural history.

Each society has its own history and past experiences consisted of differentia and caused to different traditions. Those factors lead to a disparity of social concepts, beliefs, values, and behaviors. Thai social culture has its own culture that is different from that of the others. Understanding the pattern of Thai culture within its environmental or social context will help continually comprehend the nature of Thai political culture derived from four dimensions of Thai social contexts, which affects the level of strengthening democracy in Thai society. Inevitably, consolidation of democratization will be supported by some kinds of social culture or political culture which generate values, ideologies, political behaviors, political institutions, and the development of political democracy. Thai people are now struggling for democracy, strongly motivated and striving in order to strengthen democratic development while facing with the barricades of democratization for several reasons, including the failure of democratic system to perform effectively, the variation of authoritarianism doctrines-both old and new as well, the weakness of democratic political culture in Thailand, and the lack of significant experiences in democratic consolidation. All these obstacles hinder the root of democratization underneath the values and behaviors called "authoritarian or pyramid culture", which have been creating "power distance" and consequentially promoting "social inequality". The solution of Thai social culture and democratization, thus, may require a cultural dimension of "small power distance" or participative culture instead of high power distance within authoritarian scheme. Exploring and collecting empirical data focused on this subject is beneficially important and leads to deep understanding of Thai social culture within its contexts. These gathering evidences consequently lead to the recommendation of a cultural solution to strengthen democracy in Thai society.

This research article is based on a major aspect of social or national culture known as "power culture" that not only Thailand but also other nations can be distinguished by the way they tend to deal with inequalities, including the relationship with authority. "Power of distance" is the indicator of power in social or national cultural dimension suggested to the basic question of how to handle the fact that people are unequal. Because some societies prefer favoring power and accepting the importance of hierarchy of command, while some societies express a preference for the people's right as much as those equalities. Some societies want their people to have most freedom and liberty, but some societies accept the idea that most people have to depend and rely on others. Thus, disparity among societies along value dimensions, such as power distance, helps in understanding differences in thinking, feeling, and behaving by the leaders and those led and in appreciating the theories adopted to describe culture. Measuring the degree of power distance at three levels: (a) general level of social norms and relationships; (b) organizational or workplace relationships level; and (c) political or state relationships level, was employed to grasp mentally how Thai people perceived power culture, at first, which consequently affected different values and political behavior of people in society. The higher the three levels of power distance in Thai people perception are, the less democracy strength exists.

This article was aimed to explore how Thai people, all stakeholders, or interest groups, perceived cultural pattern in dimension of "power distance" which was the effect to strengthen democracy at three levels as 
followed: (a) how Thai people perceived "power distance" of Thai social culture at general level of social norms and relationships, associated with general relationships in family (between children and adults), in school/university (between teachers and students), and in society (between youngers and olders); (b) how Thai people perceived on "power distance" at organizational or workplace relationships level, associated with relationship between superior and subordinates; (c) how Thai people perceived "power distance" at political or state relationships level, associated with relationship between leader and followers or people and government; and (d) how cultural contexts of Thai social culture among four dimensions (culture, historical sociology, organizational society, and political economy), influenced political culture and democratization. How about their impacts? This investigation was made in order to reply whether Thai social culture is the culture contributing or impeding for democracy regime. The assumption was that Thai social culture is a culture of pyramid scheme or an authoritarian one which is an intangible barrier restricting the strengthening and consolidating democracy in Thailand.

\section{Literature Review}

The literature review in this study serves two main purposes. The first is to examine the fundamental theories or concepts contributed to the research questions. They are: (a) theories on national culture and social culture-Hofstede's concept (1987) and G. Hofstede and G. J. Hofstede's concept (2005) of power culture dimension and power distance and national culture concepts of Handy (1991) and Triandis (1995); (b) concepts of Thai social culture in various perspectives from Riggs (1966), Anon (1974), Kemp (1982), Anderson (1983), Wyatt (1984), Morgan (1986), and Akin (2003); and (c) concepts of organizational society by Scott and Hart (1979) and Morgan (1986). The second purpose of the literature review is to examine which theories help explain the research findings. Those are: (a) Hofstede's concept (1987) and G. Hofstede and G. J. Hofstede's concept (2005) of "power culture" and "power distance"; (b) power distance and democracy concepts of House, Hanges, Javidan, Dorfman, and Gupta (2004) and Robbins (2003); and (c) concepts of democratization from Almond and Verba (1965), Dahl (1986), Lipset and Linz (1988), Huntington (1991), and Eland, Ensher, and Berke (2004).

\section{Thai Social Culture}

There have broad perspectives of Thai social culture from both Thai and Western thinkers that had been defined and illustrated. Embree (1969) discovered that Thai social structure is a loosely constructed pattern. The longer time he lives in Thailand, the more beliefs that Thai people is disordered, out of the rule, and lacked for discipline he has. Anon (1974) pointed out that Thai culture is a culture in dimension of individualism, since Thai people would rather do whatever they want to do depending on their preferences, by ignoring the opinions of other people. Hofstede (1987) investigated his cultural dimensions' model and found that Thai society was somewhat unique with its two highest culture by his rankings being equal at 64 -Power Distance (PDI) and Uncertainty Avoidance (UAI). The equally high Hofstede (1987) dimension ranking of UAI indicates the society's low level of tolerance for uncertainty. In an effort to minimize or reduce this level of uncertainty, strict rules, laws, policies, and regulations are adopted and implemented. The ultimate goal of Thai population is to control everything in order to eliminate or avoid the unexpected. As a result of this high uncertainty avoidance characteristic, the society does not readily accept change and is very risk adverse. While Handy (1991) analyzed that Thai culture was in the same pattern of other countries in South East Asia region 
that Zeus culture (club culture) has dominated and influenced over these countries along their histories and supported with characteristics of Apollo culture (Role culture) on their fundamental values.

As to Triandis' research (1995), he confirmed that location was the major cause which has influenced to a norm of Thai culture. Thai cultural pattern had been shaped by geographical causation, since Thai country was located between China and India. Locating between the two huge countries with their strong cultures influenced Thai social culture to be weak and loose characteristic in order to flexibly protect itself and consequentially generate risk cultural pattern with femininity scheme. On historical sociology dimension, Riggs (1966) analyzed that Thai culture was in "bureaucratic polity" system that deeply rooted in "feudalism" values, which promoted the officials in higher status and more power than people. But Kemp (1982) was straight to another dimension of patronage system in Thai society. By using "a tail wagging the dog" metaphor, Kemp (1982) explained the "Patron-Client" model in his Thai social study. Morgan (1986) gave the support that Thai culture was a "paternalism" pattern derived from "patriarchal family's value", which is the same preference one of "Asian value". Besides, Akin (2003) stated that Thai feudalism led the society into "a patronage system's preference", which could exchange the loyalty of lower power people for the protection from higher power ones. This exchange is favored by citizens of this inequality state.

As for the organizational society dimension, Denhardt (1984) suggested that organization management has influenced over human society by creating "smoke curtain" called "ethics of organization" in order to dominate people's lives. It instinctively created hierarchical culture or power culture, which required conformist person and made people automatically behave in domination values. As Morgan (1986) said that an organization was an "ugly face" of organizational life. Leader groups always make their profits by exploiting labor forces from the lower class of employers, in order to serve their values and preferences. Inequality was created intentionally, not by accidentally or consequentially affected. This pattern leads to the idea of "official nationalism" of Anderson (1983) which was coherent to that of "Elite Nationalism" followed by Wyatt (1984). Thai social culture was determined that it has had an official nationalism or elite nationalism scheme.

\section{Power Distance and Inequality}

"Power distance" is the extent to which less powerful members of institutions and organizations within a country expect and accept that power is distributed unequally (G. Hofstede \& G. J. Hofstede, 2005). Power distance describes also the extent to which employees accept that superiors have more power than they have. Furthermore, that opinions and decisions are right, because of the higher position some has. In countries with high power distance, employees are too afraid to express their doubts and disagreements with their autocratic and paternalistic bosses. Power distance is thus described based on the value system of the less powerful members. The way power is distributed is usually explained from the behavior of the more powerful members, the leaders rather than those led. The index for power distance describes the dependence of relationships in a country. From Hofstede's survey (1987), the high PDI is indicative of a high level of inequality of power and wealth within Thai society. This condition is not necessarily forced upon the population, but rather accepted by the society as a part of their cultural heritage. The ranking of 64 is slightly lower than the Asian average of 71. It is small in countries where bosses and subordinates work close together and consult each other. Subordinates and superiors consider each other as or less equal, even there is a difference in education level. The hierarchical system can always change depending on the circumstances. The hierarchies are flat with a decentralized organization and a small number of supervisors who are expected to be accessible for their subordinates. 
Within a company, the degree for unequal treatment is reduced to a low level. There is interdependence between employer and employee. The salary range is narrow between the top and bottom in companies. Subordinates expect to be consulted within the decision-making process.

Characteristics of societies that have high and low power distance follow as House et al. (2004) suggested are categorized. High power distance societies have the followed characteristics, such as society differentiated into classes, power linked to corruption and coercion, upward social mobility limited, resources available to only a few, and information localized and hoarded. Low power distance societies have characteristics in vice versa. Robbins (2003) also suggested that power distance refers to the power level which members of a society acknowledge that power was distributed inequality. Socials or organizations with high power distance are more likely to become the society of centralized power towards the leader or to become the social in pyramid schemes at high level of the hierarchy of command. Most people in society or a majority of employees do not have the managerial authority and usually come from the lower level of social and economic class.

\section{Pyramid Culture}

Pyramid culture is defined to be the cultural pattern in which society prefers values and behaviors of power centralization. The analogy of authoritarianism, authorization with command and control culture in top-down model, is illustrated by a "pyramid" picture. The pyramid represents inequality (more versus less) relying on hierarchical command and control from the top of pyramid-few power people, downwards the lower level or the basement of pyramid-mass of powerless people. This analogy suggests the concept of "power culture" proposed by G. Hofstede and G. J. Hofstede (2005) that a society's level of inequality is endorsed by the followers as much as by the leaders. Power and inequality, of course, are extremely fundamental facts that any society and anybody with some international experience will be aware that all societies are unequal, but some are more unequal than others (G. Hofstede \& G. J. Hofstede, 2005). Pyramid culture, therefore, described the culture that reflects a preference of power, an acceptance of priority on hierarchical command and control, and a belief of dependent relationship between power people and low power people, in a society.

\section{Democratization}

Power distance and democracy is automatically correlated inevitably. As Almond and Verba (1965) indicated, democracy consolidation will be supported by some kinds of social culture or political culture which generate values, ideologies, political behaviors, political institutions, and the development of political democracy. Dahl (1986) supported it by introducing the participative society with "democratic culture", "participative culture", or so-called "pancake culture" consisted of these important values: (1) values and dignity of individual; (2) autonomy and freedom of individual; (3) distrust on using power; (4) not conforming to power person; (5) honesty culture; (6) accept in difference of other people; and (7) willing to compromise and change. These attributes are opposite to the preference values in authoritarian schemes and were believed to be key success factors of participative culture leading to democratization. As to Lipset and Linz (1988), participative management is the culture that gives strong support to strengthen and consolidate democracy regime in all social. They also suggested that this culture would be created, whenever there were principles and beliefs of the following: (1) the pattern of success focusing on the ability of individuals more than nationality; (2) the seizure of internationalism values; (3) emphasizing on specific duties; (4) valuing to equality, indiscrimination, and justice; (5) the stability of social economics; and (6) democratization must be based on middle class of society. Huntington (1991) concluded in his paper that modernization would affect political 
participation of people by the process of socialization, economic development, and political culture which encouraged people to well behave in political participation, called "democratic culture". Eland et al. (2004) confirmed that strong democratization has been developed in South Africa by social and political structure changing, transferred from race discrimination to equality. This advancement ensured that power distance and inequality has been decreased in South Africa and it would have been done as to the same condition among groups of different nationalities (Eland et al., 2004). This situation consequently affects to strengthen and consolidate democracy. House et al. (2004) pointed that power of distance originated from the societies which governed by administrative government of the communist regime, since those societies had been generated high inequality by restricted power and cruel policies. Discrimination in those societies was visibly portrayed for long time, though many leaders have been changed from past generation.

\section{Theoretical Framework}

A different group of people has different ways of life, different ways to give meaning to things, and different values and behaviors. Therefore, social or national culture is dictated by the values, beliefs, behaviors, and norms which permeate their members and are expressed through the words and behaviors of those members in society. Many cultural theorists have described Thai social culture from their perspectives and proposals through various cultural dimensions. Some on cultural dimension pointed that Thai culture belonged to weak and loose pattern favored by individualism (Embree, 1969; Anon, 1974; Hofstede, 1987; G. Hofstede \& G. J. Hofstede, 2005; Handy, 1991; Triandis, 1995). On historical sociology dimension, Thai culture was seen as patronage system, spoil system, paternalism, and particularism that derived from the Feudalism ideology (Riggs, 1966; Kemp, 1982; Morgan, 1986; Akin, 2003). Thai social culture as the same one to other societies' cultures, particularly analyzed on organizational society dimension, was illustrated in hierarchical or bureaucratic culture, conformist pattern or collectivism (Triandis, 1995), and domination culture (Scott \& Hart, 1979; Morgan, 1986). It was also portrayed as the official nationalism or elite nationalism, on political economy dimension (Anderson, 1983; Wyatt, 1984).

Those attributions of Thai social culture reviewed above from many theorists, both Thai and Western, introduced Thai culture towards the pattern of power culture with high power distance followed by the research finding and the well-known national's culture conceptions (Hofstede, 1987; G. Hofstede \& G. J. Hofstede, 2005). The result indicates Thai society's low level of tolerance for uncertainty. High power distance, therefore, indicates a high level of inequality of power and wealth within Thai society and leads to social characteristic of a pyramid culture or an authoritarian one, such as a differentiated society into classes or a corruption and coercion society urged from power (House et al., 2004; Robbins, 2003). Power distance and democracy is consequently correlated and cannot be separated inevitably. Theorists on democracy concept indicated that democracy consolidation will be strongly supported by some kinds of social culture or political culture called participative culture, democratic culture, or pancake culture, which generate values, ideologies, political behaviors, political institutions, and the development of political democracy (Almond \& Verba, 1965; Dahl, 1986; Lipset \& Linz, 1988; Huntington, 1991). Almond and Verba (1965) introduced the characteristics of pancake culture or participative one, such as a civic society which values human dignity and freedom of individual, distrusts using power, and does not conform to power person. These attributes are opposite to the preference values in pyramid schemes and were believed to be key success factors of pancake culture leading to strengthen democratization, since they decrease power distance and inequality among groups of different 
nationalities (Eland et al., 2004; House et al., 2004). The theoretical framework of this article was synthesized and illustrated in Figure 1 below.

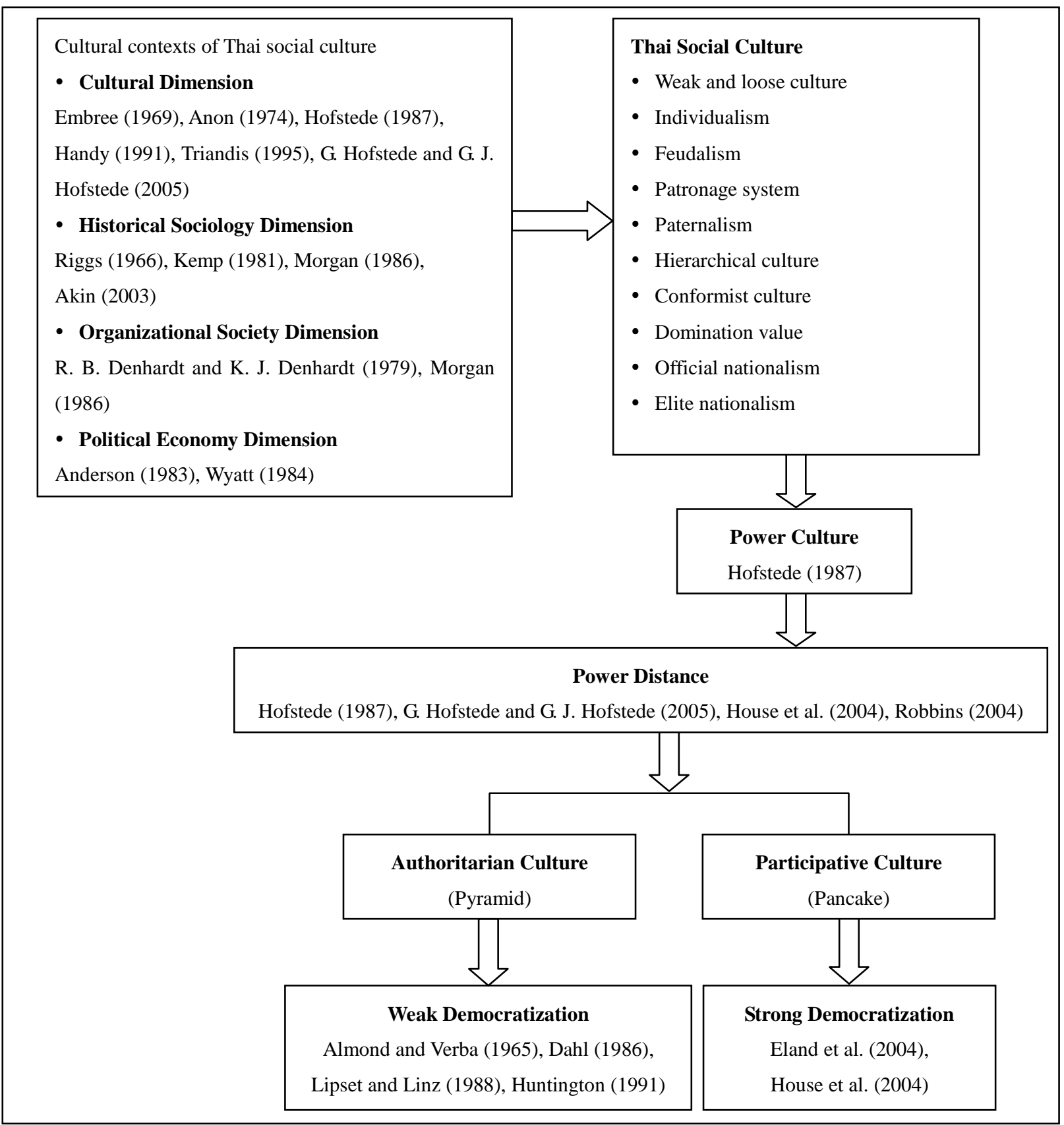

Figure 1. Theoretical framework. Source: The author's own elaboration and synthesis.

\section{Methodology}

The methodology used in this research article is mixed method by both quantitative and qualitative methods, specifically conducted by a national cultural dimension known as "power distance" dimension proposed by G. Hofstede and G. J. Hofstede (2005). A total number of 1,640 questionnaires were mailed to 13 targeted groups from all sectors of Thai society. In addition, personal interviews with 72 informants were 
purposively drawn. Both the interviewed schedule and the mailed questionnaire were modified from the test of power culture dimension and power distance indicators (G. Hofstede \& G. J. Hofstede, 2005), in order to be more relevant to the Thai context and more exclusively focus on power culture pattern, called pyramid or authoritarian culture which has affected weak democratization. The instruments were the questionnaire and structured in-depth interview modified from the power distance indicators of inequality at three levels (G. Hofstede \& G. J. Hofstede, 2005). The collected data contributed validity to the results. This research design was chosen to ensure the best opportunity to determine whether Thai social culture is the culture contributing or impeding to consolidate democracy regime. While a test provides numerical indicator of the observed phenomena, power distance, at three levels, a structured in-depth interview sheds light to the causes of those phenomena. Both selected methods thus contribute to the validity of this research.

This research paper is an exploratory attempt. The sample was selected by way of multi-stage sampling that was a blending of a simple random sampling, a purposive sampling, and a quota sampling. First, the population was segmented into mutually exclusive sub-groups based on the stakeholders or interest groups of Thai society. They were grouped by considering the three major groups of people in a political system: official groups, politician groups, and people from all career groups. All 13 career groups, then purposively had drawn from those three major groups of people (Table 1). They were all consisted of official groups, politicians, public enterprise officials, lecturers, entrepreneurs, workers from private organizations, journalists and news reporters, sellers, students, farmers, labors, disability people, and general groups. After purposively selecting 13 career groups of people, the sampling unit was then judged by quota sampling selection from various sources at 1,640 persons for statistical testing purpose, as portrayed in Table 1. From those respondents, 72 persons were chosen purposively for in-depth interviewing, sufficient and specific to explore the emergence of power distance scheme which reached a saturation point with this respondent number. The table of sampling frame, sampling unit, target population, sections of sampling unit, and sample size selected to participate in this research is shown in Table 1.

Instrumentations that had been employed to collect data were a test and a structured-interview. First, a test was designed for measuring the perceptions of the survey population, as a member of Thai society, in stakeholders or interest groups. This questionnaire was modified from the concept of national or social culture, particular on "power culture" dimension and "power distance" indicators. The questions number 1-12 were designed to explore the perception of power distance at the general level of social norms and relationships among family, school, children, and adults; the questions number 13-24 were to explore the perception of power distance at the organizational or workplace relationships level; and the questions number 25-36 were to explore the perception of power distance at the political or state relationships level. The test was improved after testing a pilot group and examined twice. The validity of the test used to collect quantitative data was ensured by considering three criteria of validity: (1) construct validity; (2) internal validity; and (3) conclusion validity. The test leads to valid conclusions or that the sample enables valid inferences. The reliability of the test was ensured by examining two criteria. The first is internal consistency: Cronbach's alpha reliability coefficient of the test is 0.686 . This Cronbach's alpha values represent the internal consistency of the items and correlation coefficients show a general description about the relationships across the constructs and sub-constructs among the proposed variables (Siegel, 2000; Howell, 2007). The second is sensitivity: The test has a discriminatory power to categorize and significantly exclude three levels of power distance. 
Table 1

The Sampling Selection by Way of Multi-stage Sampling

\begin{tabular}{|c|c|c|c|c|c|}
\hline Sampling frame & $\begin{array}{l}\text { Sampling unit } \\
\text { (Random } \\
\text { sampling) }\end{array}$ & $\begin{array}{l}\text { Target population } \\
\text { (Purposive sampling) }\end{array}$ & $\begin{array}{l}\text { Sections of } \\
\text { sampling unit } \\
\text { (Quota sampling) }\end{array}$ & $\begin{array}{l}n n \\
(1,640) \\
\text { Test }\end{array}$ & $\begin{array}{l}n \\
(72) \\
\text { Interview }\end{array}$ \\
\hline \multirow{11}{*}{ Thai people } & \multirow{11}{*}{$\begin{array}{l}\text { Stakeholders or interest groups of } \\
\text { Thai people in three major groups } \\
\text { of political system: } \\
\text {-Official groups } \\
\text {-Politician groups } \\
\text {-People from all career groups }\end{array}$} & -Official groups & $\begin{array}{l}\text { Officials, teachers, doctors, nurses, soldiers, naval } \\
\text { officers, air force officers, and policemen }\end{array}$ & 360 & 12 \\
\hline & & -Politicians & Members of the assembly, senators & 60 & 3 \\
\hline & & -Public enterprise officials & PE officials from 9 PE organizations & 150 & 10 \\
\hline & & - Lecturers & Lecturers from 13 universities & 80 & 8 \\
\hline & & - Workers of private organizations & Workers from 42 companies & 220 & 6 \\
\hline & & -Journalists \& news reporters & Workers from five companies & 100 & 4 \\
\hline & & -Sellers & $\begin{array}{l}\text { Merchants from } 10 \text { markets, four shops, and four } \\
\text { departments }\end{array}$ & 100 & 4 \\
\hline & & -Students & Students from 10 schools, 17 universities & 280 & 6 \\
\hline & & -Farmers & Farmers from 18 farms & 100 & 5 \\
\hline & & -Labors & Labors from 16 companies & 120 & 6 \\
\hline & & -General groups & NGOs, housekeepers, retired officials, and old groups & 10 & 1 \\
\hline
\end{tabular}

Source: The author's own design. 
Second, a structured-interview was designed for probing the real opinions of the subjects selected by a purposive sampling method. Data collected via these interview instruments are intended to explain the causation of power distance perceived by the respondents and the impacts of cultural contexts of Thai social culture among four dimensions: cultural dimension, historical sociology dimension, organizational society dimension, and political economy dimension, which affect consolidated democracy. The structured-interview was based on conceptual structure, from major issues, relating to the cumulative causes of power distance and democratization as per reviewed. The survey subjects were requested to share their opinions and perceptions on the following issues: (1) autonomy, freedom, and decision-making of Thai people; (2) equality, fairness, and participation of Thai people; (3) transparency, accountability, and governance of Thai society; and (4) power in Thai society.

\section{Data Analysis}

With permission granted by the target agency, data were collected and analyzed by using both methods described earlier. Data from a test were considered by the percentage ranked by categorized criterion, mean, and standard deviation analyses. The content below presents the data that characterize Thai people in their perceptions, attitudes, and opinions toward Thai social culture and democratization, indicating the level of "power distance" perceptional strength of democratic values among Thai people (Table 2).

The sample includes a very high level of respondents expressing support for power distance reflecting power culture in Thai society. Table 2 shows that $47.1 \%$ of respondents strongly agreed that inequalities among people in society are accepted in common and $46.2 \%$ of respondents strongly agreed that Thai society always prefers certificate and academic degree to knowledge - at general level of social norms and relationships. At organizational or workplace relationships level, 56.9\% of respondents strongly agreed that there is a wide salary range between the top and the bottom of the organizations and $47.0 \%$ of respondents strongly agreed that subordinates want to please superiors for their progresses. At political or state relationships level, $60.8 \%$ of respondents expressing strongly agreed that the authorities always have more privileged than ordinary people and 59.2\% of respondents expressing strongly agreed that both autocratic and oligarchic governments are based on cooptation and spoils system as well.

The data from depth-interviews were collected by way of formal and structured interviewing to explore participants' perceptions, beginning from the issues relevant to power in Thai society (Table 3) and democracy in Thai society (Table 4). The opinions of respondents on "freedom, autonomy, and the abilities of decision-making of Thai people" also leaded to explain the causes of power culture in Thai society (Table 5). By this method, 72 respondents were asked by probing with open-ended or structured questions to explore their opinions and attitudes in order to support the causation of either authoritarian or pyramid culture, or participative or pancake culture, which they perceived. The data collected by this interview could relate to the pattern of culture which aligned with the purpose of this research.

When attitudes toward power in Thai social culture are examined by the structured-interviews, the sample includes a very high level of respondents expressing support for power distance investigated by questionnaires. Table 3 shows the mean value at 4.38 of respondents strongly supported to the data collected from questionnaires that the powerful people often have more privileged than ordinary people and the mean value at 4.29 of respondents also strongly supported to the data collected from questionnaires that both autocratic and oligarchic governments are based on cooptation and spoils system as well. 
Table 2

Attitude and Perception's Level on "Distance Power" at Three Levels to the Questionnaire (Percentage, Mean, Standard Deviation Value) $(N=1,276)$

\begin{tabular}{|c|c|c|c|}
\hline Statements & $\begin{array}{l}\text { Strong } \\
\text { degree } \\
(81 \%-100 \%)\end{array}$ & $\begin{array}{l}\text { Mean } \\
(X)\end{array}$ & SD \\
\hline \multicolumn{4}{|l|}{ General level of social norms and relationships (1-12) } \\
\hline 1. Inequalities among people in society are accepted in common. & 47.1 & 2.01 & 1.209 \\
\hline 2. Social relationships should be balanced with restraint. & 26.0 & 2.28 & 1.058 \\
\hline 3. Less powerful people should be dependent on more powerful people. & 27.1 & 2.58 & 1.406 \\
\hline 4. Children are a source of old-age security to parents. & 18.3 & 2.70 & 1.185 \\
\hline 5. Parents rather teach children obedience than let them think and decide by themselves. & 26.9 & 2.40 & 1.186 \\
\hline 6. Teachers should take all initiative in class. & 21.2 & 2.48 & 1.112 \\
\hline 7. Teachers are gurus who transfer personal wisdom. & 10.4 & 2.93 & 1.104 \\
\hline 8. Quality of learning depends on excellence of teacher. & 14.6 & 2.87 & 1.199 \\
\hline 9. Students rather want to please teachers than want to have their own opinions. & 17.1 & 2.59 & 1.085 \\
\hline 10. Both more and less educated person show equally authoritarian values. & 23.4 & 2.52 & 1.201 \\
\hline 11. Educational policy focuses on universities. & 25.6 & 2.45 & 1.175 \\
\hline 12. Society always prefers certificate and academic degree to knowledge. & 46.2 & 2.09 & 1.298 \\
\hline \multicolumn{4}{|l|}{ Organizational or workplace relationships level (13-24) } \\
\hline 13. Hierarchy in organizations reflects existential equality between higher and lower level. & 45.5 & 2.06 & 1.245 \\
\hline 14. Centralization towards leader is popular in the workplace. & 42.9 & 2.04 & 1.184 \\
\hline 15. There are more supervisory personnel in organizations. & 18.4 & 2.47 & 1.043 \\
\hline 16. There is a wide salary range between the top and the bottom of the organization. & 56.9 & 1.91 & 1.291 \\
\hline 17. Managers rely on superiors and on formal rules. & 33.0 & 2.22 & 1.146 \\
\hline 18. The ideal and popular boss is a benevolent autocrat or good father. & 44.7 & 2.14 & 1.316 \\
\hline 19. Relationships between superiors and subordinates are emotional and rather depend on person than principle. & 39.8 & 2.09 & 1.169 \\
\hline 20. Privileges and status symbols are normal and popular. & 45.2 & 2.04 & 1.233 \\
\hline 21. White-collar jobs in the office are valued more than blue-collar jobs in the factory. & 44.5 & 2.08 & 1.255 \\
\hline 22. Subordinates want to please superiors for their progress. & 47.0 & 2.02 & 1.238 \\
\hline 23. Subordinates expect to be told what to do. & 17.0 & 2.44 & 0.944 \\
\hline 24. Employers always exploit over workers and rather think of their benefit than employee's quality of work life. & 33.8 & 2.26 & 1.201 \\
\hline \multicolumn{4}{|l|}{ Political or state relationships level (25-36) } \\
\hline 25. Might prevail over right: Whoever holds the power is always right and good. & 47.0 & 2.14 & 1.371 \\
\hline 26. Skills, wealth, power, and status often go together. & 37.0 & 2.19 & 1.207 \\
\hline 27. Mostly poorer countries with a small middle class tend to emphasize on power. & 36.9 & 2.16 & 1.182 \\
\hline
\end{tabular}


28. The powerful people often have more privileged than ordinary people.

$\begin{array}{lll}60.8 & 1.86 & 1.314 \\ 45.6 & 2.01 & 1.211 \\ 39.4 & 2.14 & 1.221 \\ 42.0 & 2.11 & 1.242 \\ 59.2 & 1.89 & 1.303 \\ 44.8 & 2.04 & 1.205 \\ 45.8 & 2.03 & 1.222 \\ 43.0 & 2.09 & 1.243 \\ 53.8 & 1.98 & 1.303\end{array}$

29. Political power is always based on tradition or family, charisma, and the ability to use force.

30. The way to change a political system is by changing the people at the top.

31. There is a less dialogue between political actors but more violent actions in domestic politics situations.

32. Autocratic or oligarchic governments are based on cooptation and spoil system.

33. Thai society has large income differentials, further increased by the tax system.

34. There is more perceived corruption by people but scandals are usually covered up by politicians.

35. Ordinary people are always feared of the powerful people such as police, teacher, doctor, judge, and politician.

36. Politician with discreditable on ethics can stay in political system.

Source: Results of data analyses from data collection (questionnaire) in field research (July 2009 to January 2010).

Table 3

Attitude and Perception's Level on "Power in Thai Society" to the Structured-Interviews (Mean, Standard Deviation Value) (N = 72) Statements

1. Might prevail over right: Whoever holds the power is always right and good.

2. Skills, wealth, power, and status often go together.

Mean $(X)$

3. Mostly poorer countries with a small middle class tend to emphasize on power.

3.88

$\mathrm{SD}$

4. The powerful people often have more privileges than ordinary people.

$4.01-1.021$

5. Political power is always based on tradition or family, charisma, and the ability to use force.

6. The way to change a political system is by changing the people at the top.

7. There is a less dialogue between political actors but more violent actions in domestic politics situations.

8. Autocratic or oligarchic governments are based on cooptation and spoil system.

9. Privileges and status symbols are normal and popular in Thai society.

10. Centralization towards leader is popular in the workplace and in public affairs.

11. In organizations, managers rely on superiors and on formal rules.

12. Employers always exploit over workers and rather think of their benefit than employee's quality of work life.

Source: Results of data analyses from data collection (structured-interview) in field research (July 2009 to January 2010). 
Table 4

Attitude and Perception's Level on "Democracy in Thai Society" to the Structured-Interviews (Mean, Standard Deviation Value) (N = 72)

\begin{tabular}{|c|c|c|}
\hline 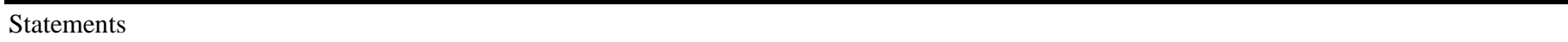 & Mean $(X)$ & SD \\
\hline 1. Thai social culture is barrier to strengthen democracy. & 3.45 & 1.202 \\
\hline 2. Inequality in society makes democracy has not been developed. & 4.03 & 1.093 \\
\hline $\begin{array}{l}\text { 3. The political changes should not focus on changing the leaders, but should } \\
\text { focus on regulatory changes or on development of democratic principles. }\end{array}$ & 4.05 & 1.092 \\
\hline $\begin{array}{l}\text { 4. Democracy is not advanced because of corruption and conflict of interest, spread by the selfish of authorities who emphasize on their personal } \\
\text { interest rather than public interest. }\end{array}$ & 4.45 & 1.041 \\
\hline 5. To democratize Thai society, all people should have equal rights. & 4.32 & 0.998 \\
\hline 6. The government should be decentralized their power more autonomously to local government, in order to strengthen democracy. & 3.78 & 1.146 \\
\hline 7. The lack of people participation in public affairs is the cause of weak democratization. & 4.05 & 1.012 \\
\hline 8. If the media is independent and not intervened, it will help monitor the performances of the government and sustain democracy. & 4.03 & 1.190 \\
\hline 9. Thai society should make priority on educational development at all levels. & 4.36 & 1.098 \\
\hline 10. Democratic society consists of decentralized government and independent people. & 4.11 & 1.125 \\
\hline 11. Economy is an obstacle factor to develop Thai society to be a democratic one. & 3.41 & 1.223 \\
\hline 12. Education is the key to the advancement of Thai democracy. & 4.36 & 1.110 \\
\hline
\end{tabular}

Source: Results of data analyses from data collection (questionnaire) in field research (July 2009 to January 2010).

Table 5

Opinion on "Freedom, Autonomy, and the Ability of Decision-Making of Thai People" to the Structured-Interviews (Percentage) $(N=72)$

\begin{tabular}{|c|c|c|}
\hline Statements and Opinions & Number & Percentage \\
\hline \multicolumn{3}{|l|}{ "Dependence" in Thai society } \\
\hline 1. Children or less power people depend on adults or people in higher positions. & 24 & 33.3 \\
\hline 2. Everyone can rely on their knowledge, not on others. & 9 & 12.5 \\
\hline 3. Both less and higher people have to rely on each other. & 14 & 19.5 \\
\hline 4. Those in higher role or position are often expected to be in dependency state for those in lower role or positions. & 20 & 27.8 \\
\hline 5. People stay on their obligations for roles independently. & 5 & 6.9 \\
\hline \multicolumn{3}{|l|}{ "Rights and freedom of thought and expression" in Thai society } \\
\hline 2. Dare not to use freedom. People are generally afraid of the authorities: teachers, doctors, police, judge, or politicians. & 18 & 25.0 \\
\hline 3. Would like to express and comment, but make sure that audiences will agree. & 2 & 2.8 \\
\hline 4. Want to exercise freedom of speech but must carefully consider about time, space, and person involved, concerning with the followed results. & 27 & 37.5 \\
\hline 5. Dare to speak and do not concern with the results to come. & 1 & 1.4 \\
\hline 6. Dare to fully speak and express their views for it is normal pattern in society. & 0 & 0.0 \\
\hline
\end{tabular}

6. Dare to fully speak and express their views for it is normal pattern in society. 
The causes and the reasons for favor pleasing to authorities or superiors in organizations

1. Having feat or preferential treatment.

2. Work together is easier.

3. Develop organizations together.

4. Being based on command line.

5. Fear of no progress.

6. Achieve to work success.

7. Do not want others to have negative attitudes about themselves as obstinate or stubborn people.

8. Be not sure of their experiences or reasons, not self-confidence.

9. Desire for personal rewards or benefits.

10. To pamper commanders, authorities.

$27 \quad 37.5$

2.8

$\begin{array}{ll}1.4 \\ 1 & 1.4\end{array}$

9.7

2.8

1926.4

26.4
6.9

The characteristics of preferable "boss" of Thai peopl

1. The leader with both power and grace at the same time.

2. The leader with "charisma power", composed by the power part—provides protection and the mercy one-gives dependable support.

3. Thai society rather favor in "person" than in "principle", as well-known in a term of "particularism".

4. A boss is a people in the higher role, being expected to use power and mercy as well in order to support his followers. 13.9

5. "Patronage regime" leads Thai society to have the boss in a pattern of "benevolent autocrat" or "good father". 13.0

6. People who have charismatic power that comes from personal prestige are appropriated with Thai society. 6.4

Why letting people free be more difficult in Thai society

1. Children are taught to obey their parents rather than have the idea themselves.

23.6

2. Students are taught to obey teachers who usually determine everything in class.

3. The workers often expected that they should be ordered to do things.

4. Most Thai people still lack of good education causing of less understanding on their right and freedom.

5. People are not promoted to participate in public affairs as those of modern state.

6. People do not participate in public policy formation or formulation process, thus public policies are the settings of elite's values, not from the demand of people.

7. Most people do not know what they want from public policy since they do not have the freedom to choose or decide on policy matters.

17

8.4

Opinions and comments on "patronage regime" and Thai society

1. Auspices of helping each other are considered as normal behavior.

2. "Patronage regime" is necessary since people usually depend on others.

3. Thai society absolutely exists in "Patronage regime" and people are used to it.

9.7

$\begin{array}{ll}7 & 9.7 \\ 2 & 2.8\end{array}$

2.8

$23 \quad 31.9$

4. "Patronage regime" is most obstacle of employing "merit system" into public management.

2

5. The reliance in patronage regime leads to inequality in Thai society.

6. Patronage regime is causation of damaging and destroying democratic values.

Source: Results of data analyses from data collection (structured-interview) in field research (July 2009 to January 2010). 
As for attitudes toward democracy in Thai society, Table 4 shows that the mean value of respondents also strongly supported to the data collected from questionnaires, especially at political or state relationships level. Most respondents are not satisfied with corruption that spread over the society. This phenomenon derived from leaders or authorities who only concern with their personal interests but neglect to those of public. The mean value at 4.45 of respondents also strongly supported that Thai people believed that democracy has been progressing slowly in Thai society, because of corruption and conflict of interest problems, expanded by the selfishness of authorities who emphasize on their personal interests rather than public interest. The mean value at 4.36 of respondents also strongly confirmed the importance of education that Thai society should give priority to educational development at all levels and education is the key to the advancement of Thai democracy.

Table 5 shows the opinions and attitudes on "freedom, autonomy, and the abilities of decision-making of Thai people", which can be analyzed and give support to the causation of either authoritarian or pyramid culture, or participative or pancake culture as perceived.

It shows that $33.3 \%$ of respondents strongly agreed that children or less power people usually depend on adults or people in higher positions. The $37.5 \%$ of respondents strongly agreed that they want to exercise freedom of speech, but must carefully consider time, space, and person involved, concerning with the followed results and indicators that the reasons for favor pleasing to superiors in organizations are to get feat and preferential treatment. The $23.6 \%$ of respondents strongly agreed that the characteristic of preferable "boss" of Thai people is the leader with "charisma power", composed by the power part-provides protection and the mercy one-gives dependable support. The $31.9 \%$ of respondents strongly agreed that most Thai people still lack of good education that caused the lack of understanding on their right and freedom. Respondents of $23.6 \%$ strongly agreed that the reliance derived from patronage regime led to inequality or partiality, from interpersonal relationships.

\section{Results}

After data collecting, from July 2009 to January 2010, findings are as follows.

\section{Conventional Culture of Thai Society}

The responses indicated that Thai culture had been constructed in pyramid schemes or authoritarian culture, since the power distance perceived culture of all three levels: (a) level of general social norms; (b) level of organization or workplace; and (c) political or state level, which were at "very high" level. These perceptions reflect pyramid cultural pattern derived from social inequalities which are the major barrier to contribute to democratization.

\section{Thai Cultural Conditions}

The social contexts of Thai authoritarian culture were vividly reflected and illustrated in pyramid scheme. The consequences of this cultural pattern directly influenced Thai political culture in "pyramid" style and weak democratization in four dimensions.

Cultural dimension. The results indicate that power distance is very high at all levels, particularly on the third level. The respondents $(60 \%)$ strongly agreed that the authorities always have more privileged than ordinary people; $47 \%$ of respondents agreed with an argument that great powers often exist over accuracy, authority who holds the power is always right and good, and rich people never be in prison; $44.8 \%$ of respondents strongly agreed that there are large income differentiations in society, further increased by the tax 
system; and $43 \%$ of respondents strongly agreed that people are generally afraid of authorities, such as police, teacher, judge, politician, and even doctor. The cultural dimension directly reflects the patterns of pyramid or authoritarian culture attacked strong democracy.

Historical sociology dimension. The findings show the power distance at the level of general norms and relationships at high level. The respondents (47.1\%) strongly agreed that inequalities among people are normal perceived; $46.2 \%$ of respondents strongly agreed that society often preferred educational degree to knowledge. Over $37 \%$ of respondents agreed that status should be balanced with restraint; $33 \%$ of respondents agreed that teachers should take all initiative in class; and $29.9 \%$ of respondents agreed that both more and less educated people show equality authoritarian values. The "obedient" and "dependent" culture in this dimension leads people to lack of freedom behavior. Following the group-think, lacking of knowledge, obeying and submitting to politicians' power, are the causes of selling votes, patronage system, nepotism, and spoils system which are the obstacles to sustain democracy.

Organizational society dimension. The study found that power distance at the second level is at "very high" level. The respondents (56.9\%) strongly agreed that there is a wide salary range between the top and the bottom of the organizations, hierarchy in organizations reflects existential inequality between higher and lower level; $47 \%$ of respondents strongly agreed that subordinates often do favors to satisfy superior for their progresses; $44.7 \%$ of respondents strongly agreed that the popular "boss" is a person with authority and charisma power and the ideal boss is a benevolent autocrat, or "good father"; $44.5 \%$ of respondents strongly agreed that white-collar jobs are valued more than blue-collar jobs. These results imply to a pattern of large authoritarian and centralized power culture in the workplace. Most workers must be commanded and accept inequality of different roles without participation.

Political economy dimension. The results indicate the power distance of political or state level at very high stage. The respondents (59.2\%) strongly agreed that autocratic or oligarchic governments are based on cooptation; $53.8 \%$ of respondents strongly agreed that politicians without ethics credibility still stand in public; $45.8 \%$ of respondents strongly agreed that there is more perceived corruption but scandals are usually covered up; $45.6 \%$ of respondents strongly agreed that political power is derived from prestige, traditional and charisma power, potential force, or political network; and $42 \%$ of respondents strongly agreed that there is less dialogue and more violence in domestic politics. This area reflects authoritarian political culture, due to the lack of civil right, fear from political power, and "corruption custom" which is a chronic obstacle of democratization.

\section{The Political Culture Indicators}

The results of qualitative data collected by in-depth interview are illustrated in Tables 3-5. Data which were collected by in-depth interview and structured-interview indicate key success factors, leading to low power distance which consolidates and strengthens democracy in Thai social culture (Table 6).

The results reveal the four political culture indicators which strongly promote sustainable democracy and also decrease the power distance in Thai social culture. They are: (1) cultural indicators: small power distance; (2) historical sociology indicators: reduction of obedience and freedom of decision; (3) organizational society indicators: participation and decentralization; and (4) political economy indicators: responsibility and transparency. These cultural dimensional contexts with indicators of Thai social culture will sustain and help strengthen democratization in Thai society as illustrated in Figure 2. 
Table 6

Political Culture Indicators That Strengthen Democratization in Thai Social Culture

\begin{tabular}{|l|l|}
\hline Cultural dimensional context & Indicators \\
\hline 1. Cultural dimension & Small power distance \\
\hline 2. Historical sociology dimension & Reduction of obedience and freedom of decision \\
\hline 3. Organizational society dimension & Participation and decentralization \\
\hline 4. Political economy dimension & Responsibility and transparency. \\
\hline
\end{tabular}

Source: Results of data analyses from data collection (questionnaire and structured-interview) in field research (July 2009 to January 2010).

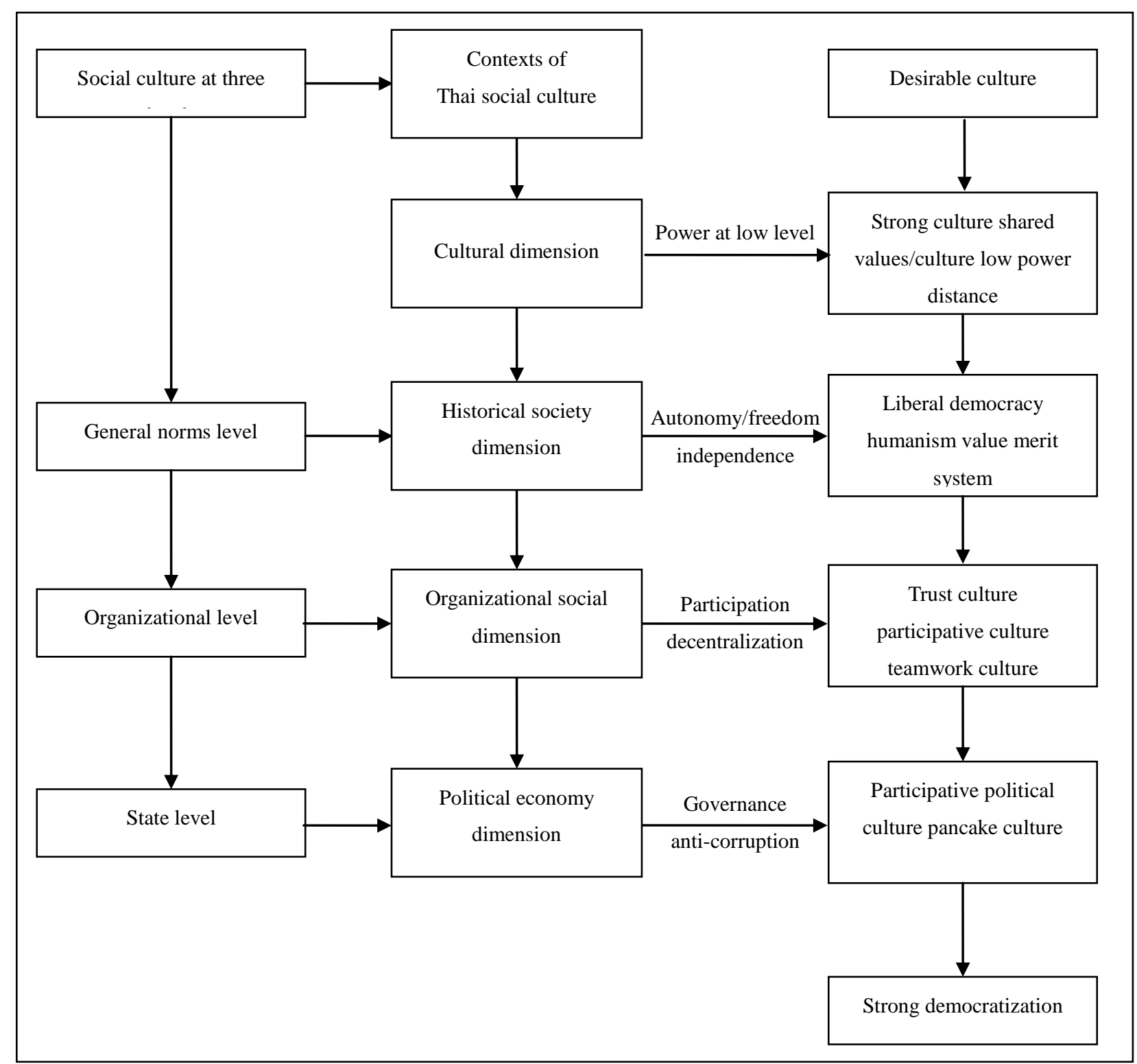

Figure 2. Desirable culture that strengthens democratization in Thai society. Source: Results of data analyses and syntheses from data collection (questionnaire and structured-interview) in field research (July 2009 to January 2010).

\section{Conclusions}


The conclusions and recommendations give support to the assumption that pyramid culture and high power distance are intangible barriers restricting to strengthen and consolidate democracy in Thailand followed the power of distance concept by G. Hofstede and G. J. Hofstede (2005). Previous studies on authoritarian culture aligned with the findings of this study are those of Almond and Verba (1965), Dahl (1986), Lipset and Linz (1988), Huntington (1991), Eland et al. (2004), and House et al. (2004). The most important thing, which public management leaders should be aware, is that democratization will be sustainable and strengthened, if pyramid culture or authoritarian culture was eliminated, by reducing inequality, minimizing reliance, reducing fear of authorities, and removing corruption. The pancake or participative culture should have been promoted instead.

\section{References}

Akin, R. (2003). Spoil system and Thai society. Nonthaburee: KPI institute.

Almond, G., \& Verba, S. (1965). The civic culture: Political attitudes and democracy in five nations. Boston: Little \& Brown.

Anderson, B. (1983). Imagined communities: Reflections on the origin and spread of nationalism. London: Verso.

Anon, A. (1974). Thai society and the problem. Bangkok: Thai Watanapanich.

Dahl, R. A. (1986). Democracy, liberty, and equality. Oslo: Nowegian University Press.

Denhardt, R. B. (1984). Theory of public organizations. Pacific Grove: Brooks/Cole, Publishing Company.

Denhardt, R. B., \& Denhardt, K. J. (1979). Public administration and the critique of domination. Administration and Society, 11, 107-120.

Eland, F., Ensher, E. A., \& Berke, W. W. (2004). Index to the journal of applied behavioral science. The Journal of Applied Behavioral Science, 40, 480-482.

Embree, J. (1969). Suye Mura: A Japanese village. Chicago: University of Chicago Press.

Handy, C. (1991). Gods of management (3rd ed.). London: Souvenir Press, Business Books.

Hofstede, G. (1987). Culture's consequences: International differences in work-related values. Beverly Hills: Sage.

Hofstede, G., \& Hofstede, G. J. (2005). Cultures and organizations: Software of the mind (2nd ed.). New York: McGraw-Hill.

House, R. J., Hanges, P. J., Javidan, M., Dorfman, P. W., \& Gupta, V. (2004). Culture, leadership, and organizations: The globe study of 62 societies. Thousand Oaks: Sage Publications.

Howell, D. C. (2007). Statistical methods for psychology (6th ed.). Belmont: Thompson-Wadsworth.

Huntington, S. P. (1991). Democracy's third wave. Journal of Democracy, 2, 12-34.

Kemp, J. H. (1982). A tail wagging the dog: The patron-client model in Thai studies. London: Pinter.

Lipset, S. M., \& Linz, J. J. (1988). Democracy in developing countries. Boulder: Lynne Rienner.

Morgan, G. (1986). Images of organization. California: Sage Publications.

Riggs, F. W. (1966). Thailand: The modernization of a bureaucratic polity. Honolulu: East-West Center Press.

Robbins, S. P. (2003). Organisational behaviour: Global and Southern African perspectives. Cape Town: Prentice-Hall.

Scott, W. G., \& Hart, D. K. (1979). Organizational America. Boston: Houghton Miffin Company.

Siegel, A. F. (2000). Practical business statistics (4th ed.). Boston: McGraw-Hill.

Triandis, H. C. (1995). Individualism and collectivism: New directions in social psychology. Boulder: Westview Press.

Wyatt, D. K. (1984). Thai landA shorth istorßBangkok: Silkworm Books. 